\title{
Understanding Online Consumer Behavior and eWOM Strategies for Sustainable Business Management in the Tourism Industry
}

\author{
Ana Reyes-Menendez ${ }^{1, *(\mathbb{D})}$, Marisol B. Correia ${ }^{2,3,4,5}\left[\right.$, Nelson Matos ${ }^{2,4}\left(\mathbb{D}\right.$ and Charlene Adap ${ }^{1}$ \\ 1 Department of Business Economics, Faculty of Social Sciences and Law, Rey Juan Carlos University, \\ Paseo Artilleros s/n, 28032 Madrid, Spain; c.adap@alumnos.urjc.es \\ 2 School of Management, Hospitality and Tourism (ESGHT), Universidade do Algarve, Campus of Penha, \\ 8005-139 Faro, Portugal; mcorreia@ualg.pt (M.B.C.); nmmatos@ualg.pt (N.M.) \\ 3 Centre for Tourism Research, Development and Innovation (CiTUR), Campus of Penha, \\ 8005-139 Faro, Portugal \\ 4 Research Centre for Tourism, Sustainability and Well-being (CinTurs), Campus of Gambelas, \\ 8005-139 Faro, Portugal \\ 5 CEG-IST, Instituto Superior Técnico, Universidade de Lisboa, 1049-001 Lisboa, Portugal \\ * Correspondence: ana.reyes@urjc.es; Tel.: +34-914-888-044
}

Received: 12 July 2020; Accepted: 23 October 2020; Published: 29 October 2020

check for updates

\begin{abstract}
Electronic word of mouth (eWOM) has been widely used by most consumers on different digital platforms. This review aimed to obtain further insights into online consumer behavior through social networking sites and online reviews sites to help tourism businesses develop sustainable eWOM strategies. To this end, an exploratory study was developed to analyze available literature on eWOM strategies and online consumer behavior. The systematic literature review analysis focused on the following two main topics: (i) tourism and (ii) eWOM. The scientific database, Web of Science, was used to collect relevant literature on the subject. The search terms "Tourism" and "eWOM" were used. Searching the database, Web of Science, yielded a total of 124 articles; upon application of different filters, a total of 14 studies were included in the final dataset. The results of the present study provide new insights into consumer behavior for social sciences and businesses for the adoption of sustainable strategies to increase the influence of eWOM on the tourism industry.
\end{abstract}

Keywords: eWOM; online reviews; online consumer behavior; management; tourism

\section{Introduction}

The continuously developing technologies and the widespread use of the Internet of Things have empowered the evolution of traditional word-of-mouth to electronic word-of-mouth, also known as eWOM [1]. Nowadays, consumers use different social platforms, including social networking sites, consumer review sites, blogs, and social communities, to communicate and share their purchase experiences on products and brands with other consumers [2-5]. The growing relevance of eWOM strategies, along with the recent Internet trends, has resulted in an increase in the number of consumer online reviews and has had an ever-growing impact on consumers' purchase decision-making [6]. In this context, electronic word-of-mouth can be considered as a powerful communication in social sciences that has enabled the shift of power from companies to consumers [4], specifically in certain industries, such as the tourism industry [7].

Table 1 from [8] summarizes the results of a study of 2830 respondents conducted to explore the influence of both positive and negative information on consumers' choices of hotels and the way consumers search for hotel information. 
Table 1. Hotel information sources for leisure travelers.

\begin{tabular}{ccc}
\hline Hotel Information Sources & Men & Women \\
\hline Metasearch websites (e.g., Expedia, Priceline, Kayak) & $40 \%$ & $44 \%$ \\
Hotel reviews posted on TripAdvisor, Facebook, Twitter, Blogs, etc. & $28 \%$ & $37 \%$ \\
Hotel reviews provided by professionals, Forbes Travel Guide, etc. & $31 \%$ & $31 \%$ \\
Colleagues and business associates recommendation & $15 \%$ & $12 \%$ \\
Friends and family recommendation & $49 \%$ & $58 \%$ \\
Travel—related websites & $43 \%$ & $41 \%$ \\
Google, Yahoo, Bing, or other search engine & $48 \%$ & $47 \%$ \\
Hotel recommended by my organization & $12 \%$ & $9 \%$ \\
\hline
\end{tabular}

Source: [8].

As can be seen in Table 1, most respondents look first for hotel recommendations from friends and family. Over 40 percent use travel-related websites, metasearch websites, Google, Yahoo, and other search engines. Almost 40 percent of female respondents look for hotel reviews on TripAdvisor and social networking sites [9]. Although there is a small difference between men and women, the results generally show that leisure travelers use many sources for hotel information.

According to the results reported by [8], there are several hotel information sources that consumers consult before the purchase decision. These sources are summarized in Table 2. Over 1600 respondents began their search for online search engines. Almost one-third of the respondents indicated that they consulted an online travel agency and a brand website. Finally, less than 600 respondents stated that they consulted other hotel information, including TripAdvisor, Facebook, and online metasearch engines.

Table 2. Information sources consulted in the early phase of a hotel purchase decision.

\begin{tabular}{cc}
\hline Hotel Information Sources & N of Respondents \\
\hline TripAdvisor & 590 \\
Facebook & 300 \\
Brand Website & 1050 \\
Online Travel Agency & 1100 \\
Online Metasearch Engines & 650 \\
Online Search Engines & 1625 \\
Read a travel book & 950 \\
\hline
\end{tabular}

Source: [8].

Table 3 shows the percentage of consumer visits on popular websites before booking accommodation [10]. According to the results, the most visited hotel websites are most popular a week before the hotel transaction when consumers are in the purchase process.

Table 3. Percentage of visits to most popular sites before the hotel transaction.

\begin{tabular}{ccccccc}
\hline Online Booking Websites & $\mathbf{5}$ Weeks + & 4 Weeks & 3 Weeks & 2 Weeks & 1 Week & Same Day \\
\hline TripAdvisor & $16 \%$ & $10 \%$ & $11 \%$ & $11 \%$ & $28 \%$ & $24 \%$ \\
Booking.com & $13 \%$ & $12 \%$ & $8 \%$ & $15 \%$ & $23 \%$ & $29 \%$ \\
Expedia & $11 \%$ & $9 \%$ & $16 \%$ & $11 \%$ & $34 \%$ & $20 \%$ \\
Choice Hotels & $10 \%$ & $9 \%$ & $11 \%$ & $17 \%$ & $12 \%$ & $40 \%$ \\
Hilton & $10 \%$ & $5 \%$ & $3 \%$ & $8 \%$ & $26 \%$ & $48 \%$ \\
\hline
\end{tabular}

Source: [10].

Reading online reviews posted by consumers in different eWOM forums has a significant effect on consumers' buying behavior [11,12]. TripAdvisor is the world's largest travel website, and over $57 \%$ of hotel clients visit TripAdvisor before making a purchase. A recent study has emphasized the growing importance to consumers of online reviews in the hospitality industry that build on the competence and commitment of consumers [1]. 
The results referred to above in Tables 1-3 were used in the present study as the foundation to explore the impact of eWOM strategies on different social platforms and to provide an overview of consumer behavior during the information search phase that was explored using a social science approach. Despite the richness of previous research on eWOM in the tourism industry, the literature is fragmented and needs to be reviewed from specific perspectives [13]. Following [8], the present study aims to thoroughly investigate online consumer behavior to help tourism businesses develop sustainable eWOM strategies.

In this study, the concept of sustainability of hotels was considered from a business perspective. Sustainable businesses were defined as companies with strong foundations that dynamically adapt to changes in the external environment and find new opportunities in the market, taking into account economic changes [14-16].

The remainder of this paper is structured as follows. In Section 2, we review previous articles to create a theoretical framework to be used in the present study. In Section 3, we explain the methodology and its implementation. The results of our exploratory analysis on the impact of eWOM on travelers' decision-making on online review sites and social networking sites are reported in Section 4. Section 5 discusses the implications of our results. Finally, conclusions for further marketing and tourism research that advance our current understanding of eWOM strategies are drawn in Section 6.

\section{Literature Review}

Over the years, numerous studies have investigated the impact of eWOM strategies on consumer purchase behavior [17,18]. Numerous industrial statistics have also highlighted the significant influence of online reviews on online consumer behavior for sustainable tourism businesses [11].

In the context of recent technological advances, electronic word-of-mouth has become a strong influencing factor in the tourism industry [19]. For instance, [20] reported that eWOM is the most important source of information that affects consumer purchase decisions regarding hospitality and tourism services. The revolution of Information and Communication Technologies (ICTs) in the last decades has transformed both traveler behavior and the tourism industry. The number of travelers who access the Internet to book hotel rooms via third-party intermediaries has grown continuously. Infomediaries, which allow users to exchange information through eWOM, have become particularly relevant in the hospitality industry during the pre-purchase stage [19]. Specifically, a previous study showed that $73 \%$ of respondents prefer to read online consumer reviews about a hotel rather than rely on the hotel's description of itself [5]. Such online reviews are visited by hundreds of millions of potential hotel visitors annually [21].

Overall, available evidence suggests that $78 \%$ of online users are influenced by online reviews in their purchase decision-making. Accordingly, online consumer reviews have become relevant sources of information for travelers and play an important role in social sciences and purchasing travel services [22].

At the same time, experiencing continuous growth over the past several decades, tourism has become one of the largest and fastest-growing economic sectors in the world. According to UNWTO, by 2030 , it is expected to reach an increase of $57 \%$, representing 1.8 billion international tourist arrivals [23]. Therefore, tourism is considered a continuously developing and highly competitive global industry that involves different sectors worldwide.

In this context, to gain a wider understanding of the continuously increasing impact of eWOM on different social platforms and its effect on the decision-making of hotel consumers, online travel sites and social networking sites should be taken into account. Accordingly, and following several previous studies, such as $[24,25]$, the present study addresses the following research question:

RQ1: Are social networks and other platforms used to develop eWOM strategies for sustainable business management in the tourism sector?

Since the aim of the present study is exploratory, we focused on exploring the trends, rather than formulate a hypothesis to be tested [24]. 


\section{Methodology}

Following the guidelines outlined in several previous studies $[8,26]$, a review study was developed to analyze available literature on eWOM and online consumer behavior for sustainable tourism businesses. The systematic literature analysis focused on the following two main topics: (i) tourism and (ii) eWOM.

The scientific databases of Scopus, PubMed, PsyINFO, ScienceDirect, and Web of Science were searched to collect the scientific articles on the subject matter. Following Banerjee et al. [27], we used a randomized controlled process to select the databases using the search terms "tourism" and "eWOM"; the timeframe was set from 2010 to 2018. The database search yielded a total of 135 articles. The Boolean operator AND was applied to optimize the results. All articles were analyzed by first reading the titles and abstracts and then selecting potentially relevant articles that met our inclusion criteria-namely: the papers had to report conclusive results and use adequate terms. This filtering resulted in discarding 84 articles and retaining 51 potentially relevant articles. In the next stage of filtering, the articles had to pass a quality evaluation; that is, only peer-reviewed papers were retained. Other criteria at this stage were the availability of keywords or description terms, relation to the research topic, and appropriate search terms. Those papers that did not meet these criteria $(n=38)$ were removed, resulting in a total of 14 studies that were included in the final dataset. Further detail on the filtering process is provided PRISMA 2009 Flow diagram (see Figure 1). The filtering criteria were based on AMSTAR [28]. Although the AMSTAR tool was initially designed to assess the quality of the articles from their abstracts, in our review, we followed the indications of [29] as an eligibility gauge.

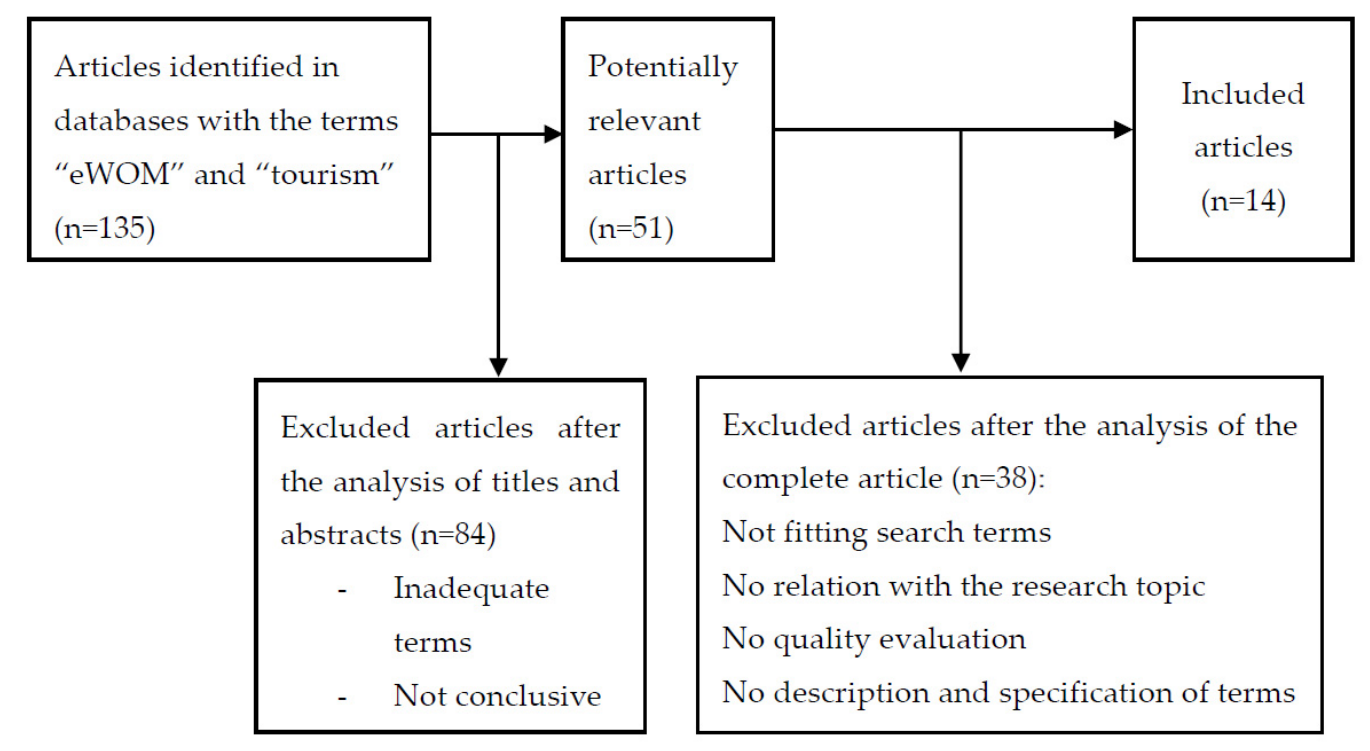

Figure 1. PRISMA 2009 flow diagram.

The aim was to achieve the highest possible amount of evidence from the results reported in high-quality studies. The variables used in AMSTAR to evaluate the quality of the articles included: (i) relationship of the research question to the criteria included in the study, (ii) extraction of data by at least two independent researchers; (iii) quality of the literature review, (iv) identification and definition of concepts; and (v) quality of the references used throughout the study.

\section{Exploratory Analysis of the Results}

The systematic literature review (SLR) has been extensively used in previous research $[18,26,30,31]$ as a tool for exploratory analysis of the obtained results. The SLR was applied to emphasize the interest of researchers in a specific topic. A literature review is a methodology of exploratory research that consists of collecting and reanalyzing existing literature on a specific subject with the aim of 
identifying and justifying the conclusions that would bring relevance to the investigation. A literature review should address both primary and secondary sources of information and take these sources of information into account.

Several previous studies, including [32,33], conducted a literature review and performed an exploratory analysis specifically in the tourism sector and social sciences; furthermore, [34] focused on the transformation of word-of-mouth into eWOM and its implications for consumer behavior for tourism businesses sustainability.

The present study was mainly based on the analysis of previous literature (see Table 4 for a summary). The reviewed articles were selected due to their focus on the same topic of interest.

Table 4. Literature review of electronic word-of-mouth (eWOM) strategies and online consumer behavior in online review sites for tourism businesses.

\begin{tabular}{|c|c|}
\hline Study & Description \\
\hline [12] & $\begin{array}{l}\text { A study of } 262 \text { subjects to establish relationships between the probability of making } \\
\text { suggestions and eWOM based on the five big personality dimensions: extraversion, } \\
\text { agreeableness, conscientiousness, neuroticism, and openness. }\end{array}$ \\
\hline [35] & $\begin{array}{l}\text { A study of } 793 \text { respondents proposes an integrative model of three social network } \\
\text { constructs associated with the website (i.e., tie strength, homophily, and source } \\
\text { credibility) and their relationship to consumers' evaluations associated with } \\
\text { attitudes and perceived influence of eWOM strategies effectiveness. }\end{array}$ \\
\hline [36] & $\begin{array}{l}\text { As little is known about the validity and applicability of cultural orientations in } \\
\text { countries with perceived inherent similar values, this study identifies the critical } \\
\text { factors that influence Chinese and Malaysian users' attitudes and behavior when } \\
\text { processing persuasive eWOM messages. }\end{array}$ \\
\hline [37] & $\begin{array}{l}\text { This study analyzes the adoption process of consumers when EC-eWOM and } \\
\text { SM-eWOM are presented simultaneously. A conceptual model is proposed to } \\
\text { reveal the relationship between the adoption of the two types of eWOM. }\end{array}$ \\
\hline [38] & $\begin{array}{l}\text { The study focuses on the influence of comments written by Facebook friends on the } \\
\text { intentions of booking a hotel, the trust in the hotel, the attitude towards the hotel, } \\
\text { and the perception of its website. The study also examines the moderator role of } \\
\text { Internet users' trust in those comments on these relations. }\end{array}$ \\
\hline [39] & $\begin{array}{l}\text { Considering eWOM communication on SNSs as a network based on the users' } \\
\text { social relationships, this study applies social network analysis to examine the } \\
\text { communication characteristics of travel-related eWOM on SNSs from the } \\
\text { perspective of both ego and whole networks. }\end{array}$ \\
\hline [40] & $\begin{array}{l}\text { This study focuses on existing frameworks and models to study negative eWOM in } \\
\text { leading social networks and its impact on brands, products, and services. }\end{array}$ \\
\hline [41] & $\begin{array}{l}\text { This study empirically examines how the two social information cues frequently } \\
\text { found on online social communities-namely, action-based social information and } \\
\text { opinion-based social information-influence consumer purchase decisions. It also } \\
\text { explains the moderating role of consumer characteristics, consumer engagement, } \\
\text { and consumer expertise. }\end{array}$ \\
\hline [42] & $\begin{array}{l}\text { The study is based on a destination-specific survey and explores summer } \\
\text { holidaymakers' motivations for social media contributions and their willingness to } \\
\text { share content through various social media. The findings in relation to the } \\
\text { destination of Mallorca offer an understanding of the adoption of tourist social } \\
\text { media in technologically-advanced markets with high levels of ICE use. }\end{array}$ \\
\hline [43] & $\begin{array}{l}\text { As few studies have directly tested potential antecedents of persuasive eWOM } \\
\text { messages among message recipients in a social media context, this study critically } \\
\text { examines the determinants of persuasive eWOM messages when message } \\
\text { recipients intend to accept and use eWOM messages. }\end{array}$ \\
\hline
\end{tabular}


Table 4. Cont.

\begin{tabular}{cl}
\hline Study & \multicolumn{1}{c}{ Description } \\
\hline [44] & $\begin{array}{l}\text { Influencers can have an important impact on the decision-making of other users. } \\
\text { Therefore, the popular eWOM community, Ciao.com, has been modeled as a social } \\
\text { network. Using social network analysis techniques, the existence of influencers is } \\
\text { justified by the power law distribution of user participation, and then they are } \\
\text { identified using their topological features within the social network. }\end{array}$ \\
\hline B & $\begin{array}{l}\text { By developing a conceptual framework for understanding the foundations of digital } \\
\text { communication, this study empirically investigates the validity of this framework } \\
\text { by examining the factors influencing tourism consumer behavior. The study adopts } \\
\text { a conceptual model of eWOM and explores the use of Twitter by tourists. }\end{array}$ \\
\hline [46] & $\begin{array}{l}\text { This paper examines the acceptance of word-of-mouth information dissemination } \\
\text { through social media. The specific focus is on the determinants of acceptance and } \\
\text { the effect of acceptance on purchase intention as the result of information on social } \\
\text { media pertaining to overseas tourism. }\end{array}$ \\
\hline [47] & $\begin{array}{l}\text { This conceptual article advances an understanding of electronic word-of-mouth in } \\
\text { presenting distinctive credibility profiles towards a proposed influence on } \\
\text { destination image and choice. }\end{array}$ \\
\hline
\end{tabular}

As can be seen in Table 4, in recent years, the concept of eWOM and social networking sites have become an object of overt-growing research interest. Among these studies, [35] reported that the homophily and tie strength between a website and a consumer are important drivers of source credibility, which influences attitude towards the reviews and the website. The attitude formed through the perceptions of tie-strength, homophily, and source credibility determines the influence of eWOM on consumers' purchase decisions.

Following the studies conducted in 2014, [36] found that argument quality, source credibility, source attractiveness, source perception, and source style exerted varying influences on Chinese and Malaysian users' attitude and intention to continue their study abroad. Researchers also showed that e-commerce-eWOM's usefulness and credibility positively influence the adoption of EC-eWOM but negatively influence that of social media-eWOM. EC-eWOM adoption was found to negatively influence SM-eWOM adoption and mediate the relationship between usefulness, credibility, and SM-eWOM adoption [37].

Furthermore, in a survey of 800 university students, [38] found the influences of comments generated on Facebook on the decision-making process. In addition, [39] established that travel-related eWOM communication via SNSs relies on existing social relationships and ties that can be categorized as strong, middle strength, or weak and that the effect of transmitted information was stronger than that of influential decision-making. Similarly, [40] studied current research of eWOM, social media, and negative eWOM strategies, while [1] highlighted the importance of eWOM in reducing the asymmetry of information.

In another relevant study, [41] discovered that consumer purchase decisions are influenced by two social information cues and that action-based social information is more influential than opinion-based social information. The authors also observed that consumer engagement and consumer expertise play an important moderating role in consumer purchase decisions. In another study, [42] clarified the dominance of visual content, along with the relevance of altruistic and community-related motivations and motivational differences between types of content creators.

Furthermore, [43] examined the determinants of persuasive eWOM messages when message recipients intend to accept and use them. Furthermore, [44] explained that influencers are not determined by the number of performed reviews but by the variety or scope of their reviews and their central position in the consumer network.

In a study on the factors affecting tourists' decision-making, [45] established that Twitter is an influential marketing channel that should be wisely used in marketing tourism services. As argued 
by [46], the professionalism of senders and the practicability of eWOM significantly affect the acceptance of information. In addition, the acceptance of eWOM information was found to have a significant effect on the spread of eWOM and customer purchase intention.

Finally, [47] focused on the understanding of electronic word-of-mouth in presenting distinctive credibility profiles towards a proposed influence on destination image and choice.

To provide an in-depth understanding of the articles included in the final sample, a full presentation of these studies is provided in Table 5 .

Table 5. Full presentation of reviewed studies.

\begin{tabular}{|c|c|c|c|c|c|}
\hline & Dependent Variable & Independent Variable & Sample & Key Findings & Topic \\
\hline [35] & $\begin{array}{l}\text { Tie strength, } \\
\text { Homophily, } \\
\text { Credibility }\end{array}$ & $\begin{array}{l}\text { Attitude towards } \\
\text { eWOM, perceived } \\
\text { influence, purchase } \\
\text { behavior }\end{array}$ & 793 & $\begin{array}{l}\text { Lack of social presence, } \\
\text { increasing skepticism about } \\
\text { eWOM credibility. Social } \\
\text { relationships between } \\
\text { consumers and websites. }\end{array}$ & $\begin{array}{l}\text { Attitudes and } \\
\text { influence of eWOM } \\
\text { for purchase }\end{array}$ \\
\hline [36] & Cultural background & $\begin{array}{l}\text { Attitudes and } \\
\text { Intention }\end{array}$ & - & $\begin{array}{l}\text { Facebook is the most used SNS } \\
\text { in Malaysia, as is QQ in China } \\
\text { Attitudes and intentions vary }\end{array}$ & $\begin{array}{l}\text { Cultural } \\
\text { differences } \\
\text { between Malaysian } \\
\text { and Chinese eWOM }\end{array}$ \\
\hline [38] & $\begin{array}{l}\text { Facebook eWOM, } \\
\text { Positive eWOM, } \\
\text { Negative eWOM }\end{array}$ & $\begin{array}{l}\text { Attitude toward hotel, } \\
\text { Booking intentions }\end{array}$ & 800 & $\begin{array}{l}\text { The existence of an influence } \\
\text { of Facebook eWOM on user } \\
\text { friends and the moderator role } \\
\text { of the trust in the } \\
\text { decision-making process for } \\
\text { hotel booking. }\end{array}$ & $\begin{array}{l}\text { eWOM in Social } \\
\text { media and its } \\
\text { influence on the } \\
\text { user decision- } \\
\text { making process }\end{array}$ \\
\hline [39] & $\begin{array}{l}\text { Contact frequency, } \\
\text { Contact duration, } \\
\text { Intimacy, Mutual } \\
\text { confiding, Social ties, } \\
\text { Travel behavior, } \\
\text { Ego-network } \\
\text { analysis }\end{array}$ & $\begin{array}{l}\text { Whole-network } \\
\text { analysis, Density, } \\
\text { Graph centralization, } \\
\text { Centrality, Subgroups }\end{array}$ & 289 & $\begin{array}{l}\text { Travel-related eWOM } \\
\text { communication via SNS relies } \\
\text { on existing social } \\
\text { relationships. The effect of } \\
\text { transmitted information is } \\
\text { stronger than that of } \\
\text { influential decision making }\end{array}$ & $\begin{array}{l}\text { Ego and Whole } \\
\text { network analysis }\end{array}$ \\
\hline [41] & $\begin{array}{l}\text { Peer consumer } \\
\text { purchase, Peer } \\
\text { consumer review, } \\
\text { Engagement, } \\
\text { Expertise }\end{array}$ & $\begin{array}{c}\text { Consumer Purchase } \\
\text { Decision }\end{array}$ & 897 & $\begin{array}{l}\text { Social information cues } \\
\text { influence consumer purchase } \\
\text { decisions. Action-based } \\
\text { information is more influential } \\
\text { than opinion-based } \\
\text { information. }\end{array}$ & $\begin{array}{l}\text { Social media } \\
\text { credibility }\end{array}$ \\
\hline$[42]$ & $\begin{array}{l}\text { Media, Types of } \\
\text { content }\end{array}$ & $\begin{array}{l}\text { Motivations for } \\
\text { sharing }\end{array}$ & 398 & $\begin{array}{l}\text { Dominance of visual content. } \\
\text { Relevance of altruistic and } \\
\text { community-related } \\
\text { motivations. Motivational } \\
\text { differences among types of } \\
\text { content creators }\end{array}$ & $\begin{array}{l}\text { Social media and } \\
\text { Tourist motivations } \\
\text { for sharing content }\end{array}$ \\
\hline [43] & $\begin{array}{l}\text { Persuasive eWOM } \\
\text { messages, } \\
\text { Information } \\
\text { acceptance, Intention } \\
\text { to use }\end{array}$ & $\begin{array}{l}\text { Argument quality, } \\
\text { Source credibility, } \\
\text { Source attractiveness, } \\
\text { Source perception, } \\
\text { Source style }\end{array}$ & 78 & $\begin{array}{l}\text { Argument quality, source } \\
\text { credibility, attractiveness } \\
\text { perception, and style are key } \\
\text { antecedents of } \\
\text { persuasive eWOM. }\end{array}$ & $\begin{array}{l}\text { Antecedents of } \\
\text { persuasive eWOM }\end{array}$ \\
\hline
\end{tabular}


Table 5. Cont.

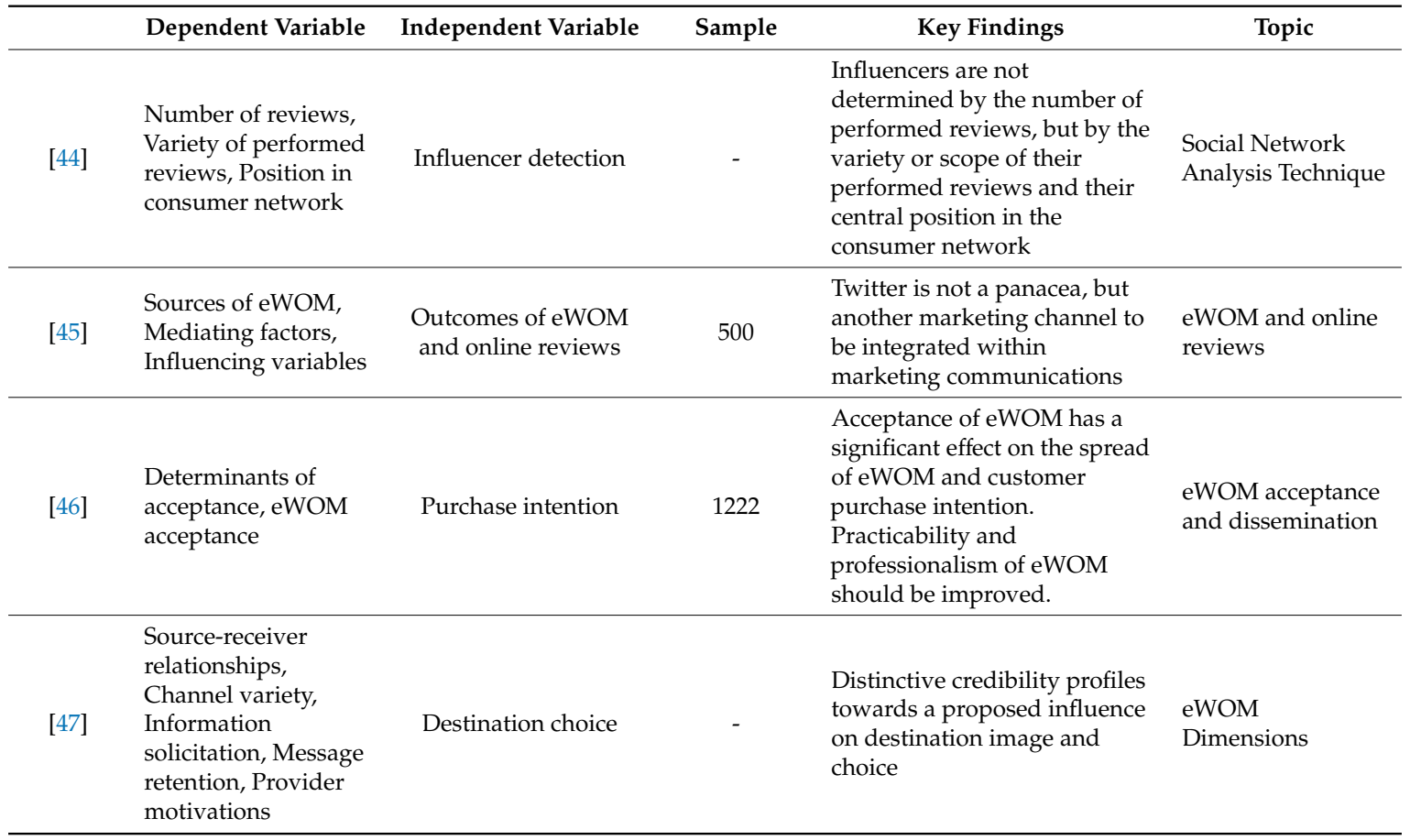

One of the main conclusions that can be derived from the analysis in Table 5 is that most reviewed studies on eWOM in tourism and its impact focused on purchase intention [35,37,38,41,43,46,47]. Exceptions here are studies that sought to expand the knowledge about eWOM in tourism, in general [45] and negative comments, in particular [40]. Several other studies aimed to deepen the understanding of the structure of social networks and influencer marketing [39,44] or explored the impact of eWOM on specific variables, such as cultural differences [36] or personal traits [12].

Then, to deepen our literature review and to unveil the adequate platforms to develop eWOM strategies, we classified the articles included in the final sample according to the social networks and platforms they focused on. The results of this classification are shown in Table 6.

Table 6. Social networks and platforms used in previous research for eWOM strategies.

\begin{tabular}{lccccc}
\hline & Facebook & TripAdvisor & Twitter & Website & SNS \\
\hline$[12]$ & - & - & - & - & $\sqrt{ }$ \\
{$[35]$} & - & - & - & - & $\sqrt{ }$ \\
{$[36]$} & - & - & - & - & $\sqrt{ }$ \\
{$[37]$} & - & - & - & $\sqrt{ }$ & $\sqrt{ }$ \\
{$[38]$} & $\sqrt{39}$ & - & - & $\sqrt{ }$ & $\sqrt{ }$ \\
{$[39]$} & - & - & - & - & $\sqrt{ }$ \\
{$[40]$} & - & - & - & $\sqrt{ }$ & $\sqrt{ }$ \\
{$[41]$} & - & - & - & $\sqrt{ }$ & $\sqrt{ }$ \\
{$[42]$} & - & - & - & - & $\sqrt{ }$ \\
{$[43]$} & - & - & - & - & $\sqrt{ }$ \\
{$[44]$} & - & - & - & - & $\sqrt{ }$ \\
{$[45]$} & - & - & - & - & - \\
{$[46]$} & - & - & - & - & $\sqrt{ }$ \\
{$[47]$} & - & - & - & - & $\sqrt{ }$ \\
\hline
\end{tabular}

Source: Authors.

Based on the results reported in Table 6, we can conclude that most of the reviewed studies did not focus on a specific social networking platform and analyzed the data in a generic way (see the last column in Table 6). This suggests that previous studies have predominantly aimed at obtaining 
a global understanding of social networks. However, each of the social platforms has its specific particularities; therefore, these specific features should be taken into account by tourism businesses to develop specific strategies for each social channel. The reviewed studies also argued that it is necessary to involve experts who dominate these social networks and ensure the success of tourism businesses in a sustainable way. An exception to this pattern is [38], where, despite having done a survey on eWOM, the questions specifically included information about Facebook (see Table 6).

Another study that also focused on a single social network is [45] that reviewed eWOM strategies used on Twitter.

Interestingly, TripAdvisor, a social tourism network par excellence, has not been analyzed specifically in any reviewed studies. This may be due to the difficulty in obtaining the data from TripAdvisor: unlike Twitter that makes it possible to connect to the API directly and thus obtain user reviews or comments, in the case of TripAdvisor, it is necessary to develop an algorithm that would allow researchers to download its data.

To conclude with the analysis of different platforms and information sources of the previous studies on eWOM, it is interesting to note that one of the columns is the company's own web page. Several reviewed studies $[37,38,40,41]$ used companies' websites as a source of information on online reviews.

Furthermore, to understand the areas of greatest interest with regard to eWOM strategies, we performed a scientometric analysis of the reviewed studies. A scientometric analysis is an analysis of scientific outcomes using a quantitative and qualitative approach. The first author to use this analysis was [48]; since then, it has been extensively used to gain a deeper understanding of the state of science in systematic literature reviews [7]. In some publications, this analysis was used as the main methodological approach [49]. Following [18], in our analysis, we first included the name of the journal, obtained from the article reference. Then we searched the journal in scientific databases, such as the Web of Science, and noted the Quartile and Category to understand the quality and impact of the reviewed articles better, as well as the categories they belong to. The results of this analysis are summarized in Table 7.

Table 7. Scientometric analysis.

\begin{tabular}{|c|c|c|c|}
\hline Journal & Total of Findings & Quartile & Category \\
\hline Psihologija & 1 & Q4 & $\begin{array}{c}\text { Psychology, } \\
\text { Multidisciplinary }\end{array}$ \\
\hline $\begin{array}{c}\text { Computers in Human } \\
\text { Behavior }\end{array}$ & 1 & Q1 & $\begin{array}{l}\text { Psychology, } \\
\text { Experimental }\end{array}$ \\
\hline $\begin{array}{l}\text { Journal of Computer } \\
\text { Information Systems }\end{array}$ & 1 & Q3 & $\begin{array}{l}\text { Computer Science, } \\
\text { Information Systems }\end{array}$ \\
\hline $\begin{array}{l}\text { Electronic Commerce } \\
\text { Research and Applications }\end{array}$ & 1 & Q2 & $\begin{array}{c}\text { Business, } \\
\text { Computer Science, } \\
\text { Information Systems, } \\
\text { Interdisciplinary Applications }\end{array}$ \\
\hline $\begin{array}{l}\text { International Journal of } \\
\text { Hospitality Management }\end{array}$ & 1 & Q1 & Hospitality, Leisure, Sport, and Tourism \\
\hline Tourism Management & 2 & Q1 & $\begin{array}{c}\text { Environmental Studies, } \\
\text { Hospitality, Leisure, Sport, and Tourism } \\
\text { Management }\end{array}$ \\
\hline $\begin{array}{l}\text { 2nd European Conference } \\
\text { on Social Media (ECSM) }\end{array}$ & 1 & - & $\begin{array}{l}\text { Communication, } \\
\text { Social Sciences }\end{array}$ \\
\hline Decision Support Systems & 1 & Q1 & $\begin{array}{c}\text { Computer Science; } \\
\text { AI } \\
\text { Operations Research and } \\
\text { Management Science }\end{array}$ \\
\hline
\end{tabular}


Table 7. Cont.

\begin{tabular}{|c|c|c|c|}
\hline Journal & Total of Findings & Quartile & Category \\
\hline $\begin{array}{l}\text { Journal of Computer } \\
\text { Information Systems }\end{array}$ & 1 & Q3 & $\begin{array}{l}\text { Computer Science, } \\
\text { Information Systems }\end{array}$ \\
\hline $\begin{array}{l}\text { Technology Analysis and } \\
\text { Strategic Management }\end{array}$ & 1 & Q3 & Management \\
\hline $\begin{array}{l}\text { International Journal of } \\
\text { Information Management }\end{array}$ & 1 & Q1 & Information Science and Library Science \\
\hline $\begin{array}{l}\text { Electronic Commerce } \\
\text { Research }\end{array}$ & 1 & Q3 & Business and Management \\
\hline $\begin{array}{l}\text { Journal of Travel and } \\
\text { Tourism Marketing }\end{array}$ & 1 & Q3 & $\begin{array}{c}\text { Hospitality, } \\
\text { Leisure, } \\
\text { Sport, and Tourism }\end{array}$ \\
\hline
\end{tabular}

Source: Authors.

As can be seen in Table 7, previous research on eWOM in tourism has been conducted in the following 14 central categories: (1) Psychology, (2) Multidisciplinary, (3) Experimental, (4) Computer Science, (5) Interdisciplinary Applications, (6) Hospitality, (7) Leisure, Sport and Tourism, (8) Environmental Studies, (9) Communication, (10) Social Sciences, (11) Artificial Intelligence, (12) Operations Research and Management Science, (13) Information Systems, Business, and Management, (14) Information Science and Library Science.

Among all the journals included in the review, only one, Tourism Management, published two articles that were included in the final dataset in the present review.

The eWOM has a computer science dimension since it involves a computer-based analysis of data from social platforms using specific algorithms needed to download user data. Accordingly, some of the reviewed studies were published in journals that belong to the Computer Science category. Another category found in our analysis is Information Systems since the information coming from social networks forms information systems used by, among others, tourism professionals. One more category that can be identified based on the results of the scientometric analysis is that of Hospitality, Leisure, Sport, and Tourism. In fact, eWOM is a particularly relevant topic in the tourism sector, as travelers' decision-making is usually supported by the comments contributed by previous visitors. Yet another category where the reviewed studies were published was Business and Management; this category is relevant, as reviews published on social networks are extensively used by the management of tourist companies.

With respect to the quality of the publications, $42.85 \%$ were Q1, while $7.14 \%$ were Q2, $35.71 \%$ were Q3, 7.14\% were Q4, and 7.14\% have no quartile. Overall, most of the reviewed studies belonged to Q1 (i.e., the highest possible ranking) and Q3. Q1 journals included reputed journals, such as Computers in Human Behavior, International Journal of Hospitality Management, Tourism Management, International Journal of Information Management, and Decision Support Systems.

Based on the results reported in this section, we can conclude that our research question (RQ1 "Are social networks and other platforms used to develop eWOM strategies for sustainable business management in the tourism sector?") can be positively answered by our results.

\section{Implications}

The results of the present study revealed the importance of eWOM strategies for the tourism industry not only on major websites but also in other types of forums, such as social networks. These venues of eWOM require managerial attention for proper brand management and to reduce the asymmetry of information that consumers get about tourism businesses [1].

The continuous growth of the tourism sector has been supported by the development of ICTs for nearly four decades. As we progress through the 21st century, the digital revolution in social 
sciences and tourism should be taken into account, as it is one of the important factors that make the industry globally competitive. Nowadays, online review sites and social media websites have become important sources of information for consumers that exert a powerful impact on online consumer behavior [1,12]. Therefore, efficient gathering and analysis of eWOM strategies can help companies to remain competitive in this industry.

However, according to the results reported in Table 6, most previous studies on the topic focused on social networks and platforms in general, rather than thoroughly analyzed tourism platforms, such as TripAdvisor or Booking.com. Accordingly, an important implication for further research on eWOM in the tourism industry is that tourism businesses should become more specific in their marketing activities rather than focus on general social networks and websites. In this way, tourism businesses can develop differentiation strategies and thus create sustainable business management.

The popularity of digital online platforms that contain online reviews and the increasing influence of eWOM on consumer behavior has driven numerous scholars to explore the phenomenon of online reviews. Considering that online reviews have become a powerful marketing tool and a success factor of many business models, in further research, it is necessary to prioritize gaining insights into the behavioral factors that influence consumers' purchase decision-making through online review sites and social media.

\section{Conclusions}

This review aimed to investigate online consumer behavior through social networking sites, online reviews sites, and platforms to help tourism businesses develop sustainable eWOM strategies. The results of our review demonstrated the ever-growing scholarly interest in the concept of eWOM strategies in social networking sites and online review sites and platforms. Despite the fact that many previous studies investigated the impact of eWOM on the hotel industry [22,50,51], there is still a need for further research due to the evolution of the industry and consumers. The relevance of the impact of eWOM strategies on the tourism industry has been acknowledged over the years, and further research to fill the gaps in our current knowledge on tourism and marketing is urgently needed.

Since tourists today live in the information era, analyzing the flows of information and identifying information asymmetry are central aspects to be considered [1].

One of the recent trends observed on online platforms and in social networks is the diversification and specialization of content [18]; accordingly, it is necessary to develop the appropriate marketing strategies not only for current placements but also for new platforms specifically developed for tourism businesses.

Moreover, tourism businesses and companies should go the extra mile to adapt their strategies in accordance with recent advances in information technologies. Adapting to the continuously changing behavior of consumers in the online tourism sector should be considered as an opportunity rather than a challenge. Understanding tourists and their online behavior will crucially impact the sustainable development of businesses within the hospitality and tourism sector [13].

In this context, the key directions that should be prioritized are market research, analysis of online consumer behavior, and appropriate use of leverages to influence purchase decision-making. In further research, it would be necessary to review the literature on eWOM in the tourism sector using quantitative techniques that enable measuring the impact of online review sites and social networking sites on consumers' decision-making related to hotel choices.

Limitations of the present review are related to the sources of the articles, the limited number of studies analyzed, and the number of previous studies consulted. Future studies should seek to get a deeper insight into some of the aspects presented in the paper, such as the information sources for eWOM strategies or the evolution of these websites. Other possible lines of development might be a quantitative analysis of information flows and online consumer behavior. 
Author Contributions: Conceptualization, A.R.-M.; methodology, A.R.-M. and C.A.; validation, N.M. and M.B.C.; formal analysis, A.R.-M.; investigation, N.M. and M.B.C.; resources, A.R.-M.; data curation, N.M. and M.B.C.; writing—original draft preparation, C.A.; writing—review and editing A.R.-M., N.M. and M.B.C.; supervision, A.R.-M. All authors have read and agreed to the published version of the manuscript.

Funding: This research was funded by National Funds provided by FCT—Foundation for Science and Technology through projects UIDB/04020/2020 and UIDB/04470/2020.

Acknowledgments: This research is a result of the stay that Ana Reyes-Menendez did under the supervision of Marisol B. Correia and Nelson Matos at Universidade do Algarve from 01/10/2018 to 31/01/2019.

Conflicts of Interest: The authors declare no conflict of interest.

\section{References}

1. Manes, E.; Tchetchik, A. The role of electronic word of mouth in reducing information asymmetry: An empirical investigation of online hotel booking. J. Bus. Res. 2018, 85, 185-196. [CrossRef]

2. Chew, S.; Metheney, E.; Teague, T. Modelling and simulation of the formation of social networks. Soc. Sci. 2017, 6, 79. [CrossRef]

3. Hubert, M.; Blut, M.; Brock, C.; Backhaus, C.; Eberhardt, T. Acceptance of smartphone-based mobile shopping: Mobile benefits, customer characteristics, perceived risks, and the impact of application context. Psychol. Mark. 2017, 34, 175-194. [CrossRef]

4. Reyes-Menendez, A.; Palos-Sanchez, P.R.; Saura, J.R.; Martin-Velicia, F. Understanding the influence of wireless communications and wi-fi access on customer loyalty: A behavioral model system. Wirel. Commun. Mob. Comput. 2018, 2018, 3487398. [CrossRef]

5. Saura, J.R.; Reyes-Menendez, A.; Palos-Sanchez, P. Un análisis de sentimiento en Twitter con machine learning: Identificando el sentimiento sobre las ofertas de\#BlackFriday. Rev. Espacios. 2018, 39, 16.

6. Zhang, K.Z.; Cheung, C.M.; Lee, M.K. Examining the moderating effect of inconsistent reviews and its gender differences on consumers' online shopping decision. Int. J. Inf. Manag. 2014, 34, 89-98. [CrossRef]

7. Saura, J.R.; Palos-Sanchez, P.; Reyes-Menendez, A. Marketing a través de aplicaciones móviles de turismo (m-tourism). Un estudio exploratorio. Int. J. World Tour. 2017, 4, 45-56. [CrossRef]

8. McCarthy, L.; Stock, D.; Verma, R. How travelers use online and social media channels to make hotel-choice decisions. Cornell Hosp. Rep. 2010, 10, 6-18.

9. Anastasiei, B.; Dospinescu, N. Facebook advertising: Relationship between types of message, brand attitude and perceived buying risk. Ann. Constantin Brancusi Univ. Targu-Jiu 2017, 6, 18-26.

10. Comscore. Comscore Score Worldwide Path to Purchase Report. Available online: https://www.comscore. com/Products/Marketing-Impact/Path-to-Purchase-Research (accessed on 1 January 2020).

11. Abubakar, A.M. Does eWOM influence destination trust and travel intention: A medical tourism perspective. Econ. Res. Ekon. Istraživanja 2016, 29, 598-611. [CrossRef]

12. Anastasiei, B.; Dospinescu, N. A model of the relationships between the Big Five personality traits and the motivations to deliver word-of-mouth online. Psihologija 2018, 51, 215-227. [CrossRef]

13. Hossain, M.; Jahan, N.; Fang, Y.; Hoque, S. Nexus of electronic word-of-mouth to social networking sites: A sustainable chatter of new digital social media. Sustainability 2019, 11, 759. [CrossRef]

14. European Commission. Mainstreaming Sustainable Development into EU Policies 2009; Review of the European Union Strategy for Sustainable Development: Brussels, Belgium, 2009.

15. Ehnert, I.; Harry, W.; Zink, K.J. (Eds.) Sustainability and Human Resource Management: Developing Sustainable Business Organizations; Springer Science \& Business Media: Berlin, Germany, 2013; ISBN 9783642375248.

16. Reyes-Menendez, A.; Saura, J.R.; Alvarez-Alonso, C. Understanding\# WorldEnvironmentDay user opinions in Twitter: A topic-based sentiment analysis approach. Int. J. Environ. Res. Public Health 2018, 15, 2537.

17. Palos-Sanchez, P.R.; Correia, M.B. The collaborative economy based analysis of demand: Study of Airbnb case in Spain and Portugal. J. Theor. Appl. Electron. Commer. Res. 2018, 13, 85-98. [CrossRef]

18. Reyes-Menendez, A.; Saura, J.R.; Filipe, F. The importance of behavioral data to identify online fake reviews for tourism businesses: A systematic review. Peer J. Comput. Sci. 2019, 5, e219. [CrossRef]

19. Papathanassis, A.; Knolle, F. Exploring the adoption and processing of online holiday reviews: A grounded theory approach. Tour. Manag. 2011, 32, 215-224. [CrossRef] 
20. Pai, M.Y.; Chu, H.C.; Wang, S.C.; Chen, Y.M. Electronic word of mouth analysis for service experience. Expert Syst. Appl. 2013, 40, 1993-2006. [CrossRef]

21. Saura, J.R.; Reyes-Menendez, A.; Filipe, F. Comparing data-driven methods for extracting knowledge from user generated content. J. Open Innov. Technol. Mark. Complex. 2019, 5, 74. [CrossRef]

22. Mauri, A.G.; Minazzi, R. Web reviews influence on expectations and purchasing intentions of hotel potential customers. Int. J. Hosp. Manag. 2013, 34, 99-107. [CrossRef]

23. World Tourism Organization. UNWTO Tourism Highlights 2017 Edition. Available online: https://www.eunwto.org/doi/pdf/10.18111/9789284419029 (accessed on 1 January 2020).

24. Robson, C. Real World Research: A Resource for Social Scientists and Practitioner-Researchers, 2nd ed.; Blackwell: Oxford, UK, 2002; ISBN 978-0631213055.

25. Ritchie, J.; Lewis, J.; Nicholls, C.M.; Ormston, R. (Eds.) Qualitative Research Practice: A Guide for Social Science Students and Researchers, 2nd ed.; Sage: London, UK, 2013; ISBN 978-1446209127.

26. Tranfield, D.; Denyer, D.; Smart, P. Towards a methodology for developing evidence-informed management knowledge by means of systematic review. Br. J. Manag. 2003, 14, 207-222. [CrossRef]

27. Banerjee, A.; Duflo, E.; Glennerster, R.; Kinnan, C. The miracle of microfinance? Evidence from a randomized evaluation. Am. Econ. J. Appl. Econ. 2015, 7, 22-53. [CrossRef]

28. Shea, B.J.; Hamel, C.; Wells, G.A.; Bouter, L.M.; Kristjansson, E.; Grimshaw, J.; Henry, D.A.; Boers, M. AMSTAR Is a Reliable and Valid Measurement Tool to Assess the Methodological Quality of Systematic Reviews. Available online: https://www.ncbi.nlm.nih.gov/pubmed/19230606 (accessed on 12 September 2017).

29. Bosch, M.V.; Sang, A.O. Urban natural environments as nature based solutions for improved public healthA systematic review of reviews. Environ. Res. 2017, 158, 373-384. [CrossRef] [PubMed]

30. Bassett, D.J. Who wants to live forever? Living, dying and grieving in our digital society. Soc. Sci. 2015, 4, 1127-1139. [CrossRef]

31. Thorpe, R.; Holt, R.; Macpherson, A.; Pittaway, L. Using knowledge within small and medium-sized firms: A systematic review of the evidence. Int. J. Manag. Rev. 2005, 7, 257-281. [CrossRef]

32. Luo, Y.; Chen, Y.; Zheng, W. A literature review on evaluating tourism destinations. In ISME 2016-Information Science and Management Engineering IV; SCITEPRESS-Science and Technology Publications: Wuhan, China, 2016; pp. 329-334. ISBN 978-989-758-208-0.

33. Comerio, N.; Strozzi, F. Tourism and its economic impact: A literature review using bibliometric tools. Tour. Econ. 2018, 25, 109-131. [CrossRef]

34. Huete-Alcocer, N. A literature review of word of mouth and electronic word of mouth: Implications for consumer behavior. Front. Psychol. 2017, 8, 1256. [CrossRef]

35. Kim, S.; Kandampully, J.; Bilgihan, A. The influence of eWOM communications: An application of online social network framework. Comput. Hum. Behav. 2018, 80, 243-254. [CrossRef]

36. Teng, S.; Khong, K.W.; Chong, A.Y.L.; Lin, B. Persuasive electronic word-of-mouth messages in social media. J. Comput. Inf. Syst. 2017, 57, 76-88. [CrossRef]

37. Yan, Q.; Wu, S.; Wang, L.; Wu, P.; Chen, H.; Wei, G. E-WOM from e-commerce websites and social media: Which will consumers adopt? Electron. Commer. Res. Appl. 2016, 17, 62-73. [CrossRef]

38. Ladhari, R.; Michaud, M. eWOM effects on hotel booking intentions, attitudes, trust, and website perceptions. Int. J. Hosp. Manag. 2015, 46, 36-45. [CrossRef]

39. Luo, Q.; Zhong, D. Using social network analysis to explain communication characteristics of travel-related electronic word-of-mouth on social networking sites. Tour. Manag. 2015, 46, 274-282. [CrossRef]

40. Kini, R. Social media and negative eWOM, and impact-current research and implications. In Proceedings of the 2nd European Conference on Social Media 2015 (ECSM 2015); Academic Conferences Limited: Porto, Portugal, 2015.

41. Cheung, C.M.; Xiao, B.S.; Liu, I.L. Do actions speak louder than voices? The signaling role of social information cues in influencing consumer purchase decisions. Decis. Support Syst. 2014, 65, 50-58. [CrossRef]

42. Munar, A.M.; Jacobsen, J.K.S. Motivations for sharing tourism experiences through social media. Tour. Manag. 2014, 43, 46-54. [CrossRef]

43. Teng, S.; Wei Khong, K.; Wei Goh, W.; Yee Loong Chong, A. Examining the antecedents of persuasive eWOM messages in social media. Online Inf. Rev. 2014, 38, 746-768. [CrossRef]

44. Arenas-Márquez, F.J.; Martínez-Torres, M.R.; Toral, S.L. Electronic word-of-mouth communities from the perspective of social network analysis. Technol. Anal. Strateg. Manag. 2014, 26, 927-942. [CrossRef] 
45. Sotiriadis, M.D.; Van Zyl, C. Electronic word-of-mouth and online reviews in tourism services: The use of twitter by tourists. Electron. Commer. Res. 2013, 13, 103-124. [CrossRef]

46. Zhang, Z.; Kim, H.M. Factor analysis of word-of-mouth information acceptance about international tourism service through social media. Int. Commer. Inf. Rev. 2013, 15, 391-418. [CrossRef]

47. Tham, A.; Croy, G.; Mair, J. Social media in destination choice: Distinctive electronic word-of-mouth dimensions. J. Travel Tour. Mark. 2013, 30, 144-155. [CrossRef]

48. Price, D.J. Little Science, Big Science; Columbia University Press: New York, NY, USA, 1963.

49. Kullenberg, C.; Kasperowski, D. What is citizen science? A scientometric meta-analysis. PLoS ONE 2016, 11, e0147152. [CrossRef]

50. Vermeulen, I.E.; Seegers, D. Tried and tested: The impact of online hotel reviews on consumer consideration. Tour. Manag. 2009, 30, 123-127. [CrossRef]

51. Xie, H.J.; Miao, L.; Kuo, P.J.; Lee, B.Y. Consumers' responses to ambivalent online hotel reviews: The role of perceived source credibility and pre-decisional. Int. J. Hosp. Manag. 2011, 30, 178-183.

Publisher's Note: MDPI stays neutral with regard to jurisdictional claims in published maps and institutional affiliations.

(C) 2020 by the authors. Licensee MDPI, Basel, Switzerland. This article is an open access article distributed under the terms and conditions of the Creative Commons Attribution (CC BY) license (http://creativecommons.org/licenses/by/4.0/). 